\title{
Effect of Genotype $\times$ Environment Interaction for Seed Traits in Winter Oilseed Rape (Brassica napus L.)
}

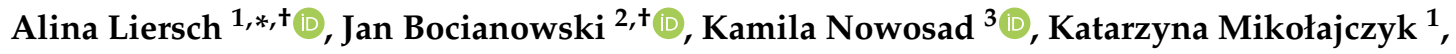 \\ Stanisław Spasibionek ${ }^{1}$, Franciszek Wielebski ${ }^{1}$, Marcin Matuszczak ${ }^{1}{ }^{1}$, Laurencja Szała ${ }^{1}$,

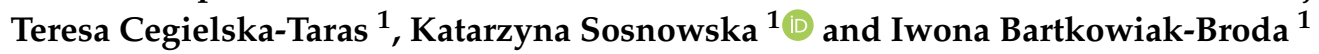 \\ 1 Department of Genetics and Breeding of Oilseed Crops, Plant Breeding and Acclimatization \\ Institute-National Research Institute, Strzeszyńska 36, 60-479 Poznań, Poland; \\ k.mikolajczyk@ihar.edu.pl (K.M.); sspas@nico.ihar.poznan.pl (S.S.); fwiel@nico.ihar.poznan.pl (F.W.); \\ marmat@nico.ihar.poznan.pl (M.M.); lszala@nico.ihar.poznan.pl (L.S.); tceg@nico.ihar.poznan.pl (T.C.-T.); \\ k.sosnowska@nico.ihar.poznan.pl (K.S.); ibart@nico.ihar.poznan.pl (I.B.-B.) \\ 2 Department of Mathematical and Statistical Methods, Faculty of Agronomy and Bioengineering, \\ Poznań University of Life Sciences, Wojska Polskiego 28, 60-637 Poznań, Poland; \\ jan.bocianowski@up.poznan.pl \\ 3 Department of Genetics, Plant Breeding and Seed Production, Wrocław University of Environmental and \\ Life Sciences, Grunwaldzki 24A, 53-363 Wrocław, Poland; kamila.nowosad@upwr.edu.pl \\ * Correspondence: alal@nico.ihar.poznan.pl \\ + These authors contributed equally to this work.
}

Received: 26 October 2020; Accepted: 4 December 2020; Published: 8 December 2020

\begin{abstract}
Brassica napus (L.), winter oilseed rape (WOSR) or canola, is one of the most important oilseed crop species of the moderate climate zone. Improving the seed quality and yield makes the main target in breeding programs worldwide. In this study, we examined the genotype-by-environment $(\mathrm{G} \times \mathrm{E})$ interaction with respect to six seed traits among 25 WOSR genotypes. The plant material included the registered canola cultivars, our newly developed mutant breeding lines and the Ogura F1 hybrids and their parental components, in addition to our domestic breeding lines including two semi-resynthesized (semi-RS) lines. The 25 genotypes were examined in field trials at two locations, in three growing seasons. Seed oil and protein content, total glucosinolates (GLS) content in seed meal and C18 unsaturated fatty acid (oleic, linoleic and linolenic) composition in seed oil were examined. The additive main effects and multiplicative interaction (AMMI) analyses revealed significant effects of both, genotype $(G)$ and environment $(E)$ as well as the $G \times E$ interaction regarding the analyzed seed traits. In our study, two Ogura F1 hybrids, a CMS line and a new high oleic mutant breeding line revealed high stability and good average values for most of the analyzed seed traits, thus making a valuable source of starting materials for further improvement.
\end{abstract}

Keywords: Brassica napus; seed traits; oil content; fatty acids composition; glucosinolates content; protein content; AMMI; biplot; adaptability; stability

\section{Introduction}

Oilseed rape (Brassica napus L., also known as rapeseed or canola) is the second major oilseed crop cultivated worldwide, after soybeans. In the last 15 years, the global production of rapeseed has doubled, reaching over 60 million tons, with a grain production of almost 71 million tons recorded in the marketing year of 2018/2019 [1]. In Poland and other European countries characterized by moderate climate conditions, winter oilseed rape (WOSR) is considered as the most important oil-protein crop [2-5]. Since the 1960s, there has been a strong selection pressure to develop double-low (canola) oilseed rape producing seeds characterized by a very low content of erucic acid (C22:1, no more 
than $2 \%$ ) and a significantly lowered glucosinolates (GLS) content (less than $25 \mu$ mole $\mathrm{g}^{-1}$ of seeds), as compared to over $50 \%$ of erucic acid and until $160 \mu$ mole $^{-1}$ of seeds of GLS, respectively, in the 'traditional' oilseed rape cultivars. Furthermore, oil derived from canola cultivars is optimal not only for human diet but is also suitable as feedstock. Moreover, canola oil can be applied as a raw material for the production of transport fuels (biodiesel, bio-jet) and other products, as soaps, surfactants, biodegradable plastics, operating supplies including lubricating and hydraulic oils, as well as release agents and basic substances for cosmetics [1,6-8].

The mature seeds of canola cultivars contain $45-47 \%$ of oil and $20-24 \%$ of valuable protein. Canola oil contains about $62 \%$ of oleic acid (C18:1), 20\% of linoleic acid (C18:2), $10 \%$ of linolenic acid (C18:3) and 7\% of saturated fatty acids, palmitic (C16:0) and stearic acid (C18:0), in addition to bioactive compounds and antioxidants [9]. Such oil is recognized as one of the healthiest vegetable oils due to its attractive composition of fatty acids [10]. However, selection of high-oleic (more than 75\% of C18:1 in seed oil) and low-linolenic (less than 3\% of C13:3) (HOLL) canola has gaining much attention since over the past two decades, as such oil is optimal for long storage and reveals high thermostability, due to its high oxidation resistance and the reduced formation of harmful trans-isomers while processing. Therefore, such oil is suitable, among others, as a raw material for biofuel production and in the food industry for deep frying [11,12].

Post-extraction oilseed rape meal is globally considered as the second source of feed protein, after the soybean meal. The EU countries, including Poland, reveal the feed protein deficit at the level of $50-70 \%$ and therefore are dependent on the North and South America soybeans import. Canola seed meal contains approximately $38-44 \%$ of valuable protein, comprising a high content of sulphur amino acids (methionine and cystine), in addition to phosphorus and calcium. It is mainly suitable as forage for livestock, as cattle, pigs, and, to a lesser extent for poultry since its fodder value, regarding protein content and nutritional quality is lower in comparison with the soybean meal. Moreover, canola seed meal contains a twofold higher content of dietary fiber than soybeans, as well as antinutritional compounds, as GLS, phenolic acids, sinapine, tannins, as well as soluble fiber $[8,13]$. Therefore, reducing these antinutritional factors makes a goal of canola breeding programs aimed at enhancing both, the seed yield and quality.

Expression of seed traits is influenced by genotype (G), environment (E) and genotype-by-environment $(\mathrm{G} \times \mathrm{E})$ interactions $[8,12,14]$. Hence, for the precise estimation of these traits phenotyping should be carried out in replicated, multi-environmental field trials. Friedt and Snowdon [7] and also Bocianowski et al. [15] have reported that seed oil and GLS content, as well as the composition of seed oil fatty acids, are modified by environmental factors such as water availability, temperature and the length of growing period. Therefore, many attempts are being undertaken worldwide to understand the importance of $\mathrm{G} \times \mathrm{E}$ interactions by means of genetic study in the long-term crop plant breeding programs using multiplicative field trials $[16,17]$.

$\mathrm{G} \times \mathrm{E}$ interactions in field trials can be analyzed by application of the additive main effects and multiplicative interaction (AMMI) model [18], which determines the genotypes characterized by a high mean value of an observed trait and a considerable adaptability to the desired area using the analysis of variance (ANOVA) and mega-environment delineation. This model combines ANOVA with additive parameters and the principal component analysis (PCA) with multiplicative parameters in a single analysis. As a result, the AMMI biplot graphic simultaneously displays both, the main and interaction effects for genotypes and environments and thus enables a single analysis of the $\mathrm{G} \times \mathrm{E}$ interaction. For this reason, AMMI is also known as interaction PCA (IPCA) [19].

In this study, we aimed to assess the $\mathrm{G} \times \mathrm{E}$ interaction for six seed traits, as oil content, as well as C18:1, C18:2 and C18:3 fatty acids content, in addition to total GLSs content and protein content in WOSR genotypes of different origin. Field trials were conducted in six environments (two locations and three growing seasons) and the statistical analysis was done using the AMMI model. 


\section{Materials and Methods}

\subsection{Plant Material}

A total of 25 WOSR genotypes were tested in field trials: seven canola cultivars-Monolit, Brendy, Starter, Mendel, Sherlock, Zornyj and Polka-the new Polish cultivar derived from a high oleic mutant line [20,21], three new Polish Ogura CMS F1 hybrids under development and their parental lines-the Ogura CMS and the Rfo restorer lines. The hybrid seeds were produced in isolation tents under field conditions. Moreover, our domestic breeding lines of different characteristics were included in the trials: one HOLL mutant recombinant, two high oleic recombinants, one new canola-type recombinant, as well as one yellow-seeded and two semi-RS lines (Table 1).

Table 1. Genotype description.

\begin{tabular}{|c|c|c|c|}
\hline Code & Description & Quality/Category & Reference \\
\hline G01 & Monolit & OP canola cultivar, PL & www.coboru.pl; [22]) \\
\hline G02 & Brendy & OP canola cultivar, $\mathrm{PL}$ & www.coboru.pl \\
\hline G03 & Starter & OP canola cultivar, PL & www.coboru.pl \\
\hline G04 & Mendel & F1 hybrid variety, NPZ, DE & www.coboru.pl \\
\hline G05 & DH_D $\times C$ & DH canola breeding line & [23] \\
\hline G06 & Z 114 & DH yellow seeded canola breeding line & {$[24,25]$} \\
\hline G07 & Rfo_37 & DH Rfo canola breeding line & {$[26,27]$} \\
\hline G08 & Rfo_38 & DH Rfo canola breeding line & {$[26,27]$} \\
\hline G09 & Rfo_39 & DH Rfo canola breeding line & {$[26,27]$} \\
\hline G10 & CMS_64 & Ogura CMS canola breeding line & {$[28]$} \\
\hline G11 & CMS_313 & Ogura CMS canola breeding line & [28] \\
\hline G12 & CMS_1612 & Ogura CMS canola breeding line & [28] \\
\hline G13 & HO_SS & HO mutant canola breeding line & [20] \\
\hline G14 & 00_SS & canola breeding line & [21] \\
\hline G15 & HOLL_SS & HOLL mutant canola recombinant line & [14] \\
\hline G16 & Polka & $\begin{array}{l}\text { HO OP canola cultivar developed from } \mathrm{HO} \\
\text { mutant recombinant breeding line, } \mathrm{PL}\end{array}$ & www.coboru.pl; [21] \\
\hline G17 & HO_TP & $\begin{array}{l}\text { DH canola breeding line developed from a } \\
\text { domestic recombinant with } \mathrm{HO} \text { acid content }\end{array}$ & [21] \\
\hline G18 & HO_TP_00 & $\begin{array}{l}\text { DH canola breeding line developed from a } \\
\text { domestic recombinant with HO acid content }\end{array}$ & [21] \\
\hline G19 & F1_952 & Ogu-INRA F1 canola hybrid under development & This study \\
\hline G20 & S43 & Semi-RS canola breeding line & [4] \\
\hline G21 & S1 & DH semi RS Rfo canola breeding line & {$[4]$} \\
\hline G22 & Sherlock & OP canola cultivar, KWS, DE & www.coboru.pl \\
\hline G23 & Zornyj & OP canola cultivar, UA & \\
\hline G24 & F1_S2 & Ogu-INRA F1 canola hybrid under development & This study \\
\hline G25 & F1_239 & Ogu-INRA F1 canola hybrid under development & This study \\
\hline
\end{tabular}

OP, open pollinated; DH, doubled haploid; Rfo Ogu-INRA restorer line; CMS, cytoplasmic male sterility; HO, high-oleic; LL low-linolenic; semi-RS, semi-resynthesized line (line obtained by crossing oilseed rape $\times$ resynthesized (RS) Brassica napus); PL, Poland; DE, Germany; UA, Ukraine.

\subsection{Field Trials and Weather Conditions}

Field trials were carried out in six environments (E1-E6) - in two locations, Borowo $\left(52^{\circ} 07^{\prime} 12^{\prime \prime} \mathrm{N}\right.$, $\left.16^{\circ} 47^{\prime} 19^{\prime \prime} \mathrm{E}\right)$ and Łagiewniki (51 $\left.45^{\prime} 40^{\prime \prime} \mathrm{N}, 17^{\circ} 14^{\prime} 13^{\prime \prime} \mathrm{E}\right)$, during three growing seasons, 2014/2015, 2015/2016 and 2016/2017, in a randomized complete block design with four replicates and a plot size of $10 \mathrm{~m}^{2}$ (in Borowo) and $9.6 \mathrm{~m}^{2}$ (in Łagiewniki). The analyzed oilseed rape genotypes were grown in four-row plots, with a row distance of $0.30 \mathrm{~m}$ and with a sowing density of 70 seeds $/ \mathrm{m}^{2}$. Sowing dates were as follows: 25 and 27 August 2014, 27 and 27 August 2015 and 27 and 29 August 2016 in Borowo (E1-E3) and Łagiewniki (E4-E6), respectively. Seeds were harvested on 28 and 20 July in 2015, 26 and 27 July in 2016 and 27 and 21 July in 2017, respectively, at the seed maturity stage using a plot harvester. All agricultural practices were carried out optimally according to the local agroecological conditions in both of the investigated locations. Field experiments were conducted on podzolic soils (sandy soil) of quality class IIIa (E1, E2) and IVa (E3) in Borowo and on typical brown soil (sandy loam and sandy clay 
loam) of quality class IIIa in Łagiewniki (E4-E6). The topsoil was slightly acidic and its $\mathrm{pH}$ values ranged from 6.0 (E1-E3) to 6.2 (E4 and E6). The crops that were cultivated previously on the soil were spring barley (E1, E5), winter triticale (E2 and E3), winter wheat (E4) and spring wheat (E6). Complex of agricultural usefulness were good wheat in E1, E2, E4, E5 and E6 and good rye in E3. The monthly temperatures and precipitations in each growing season, from the beginning of May (flowering) till the ending of July (harvest) are presented in Figure 1.

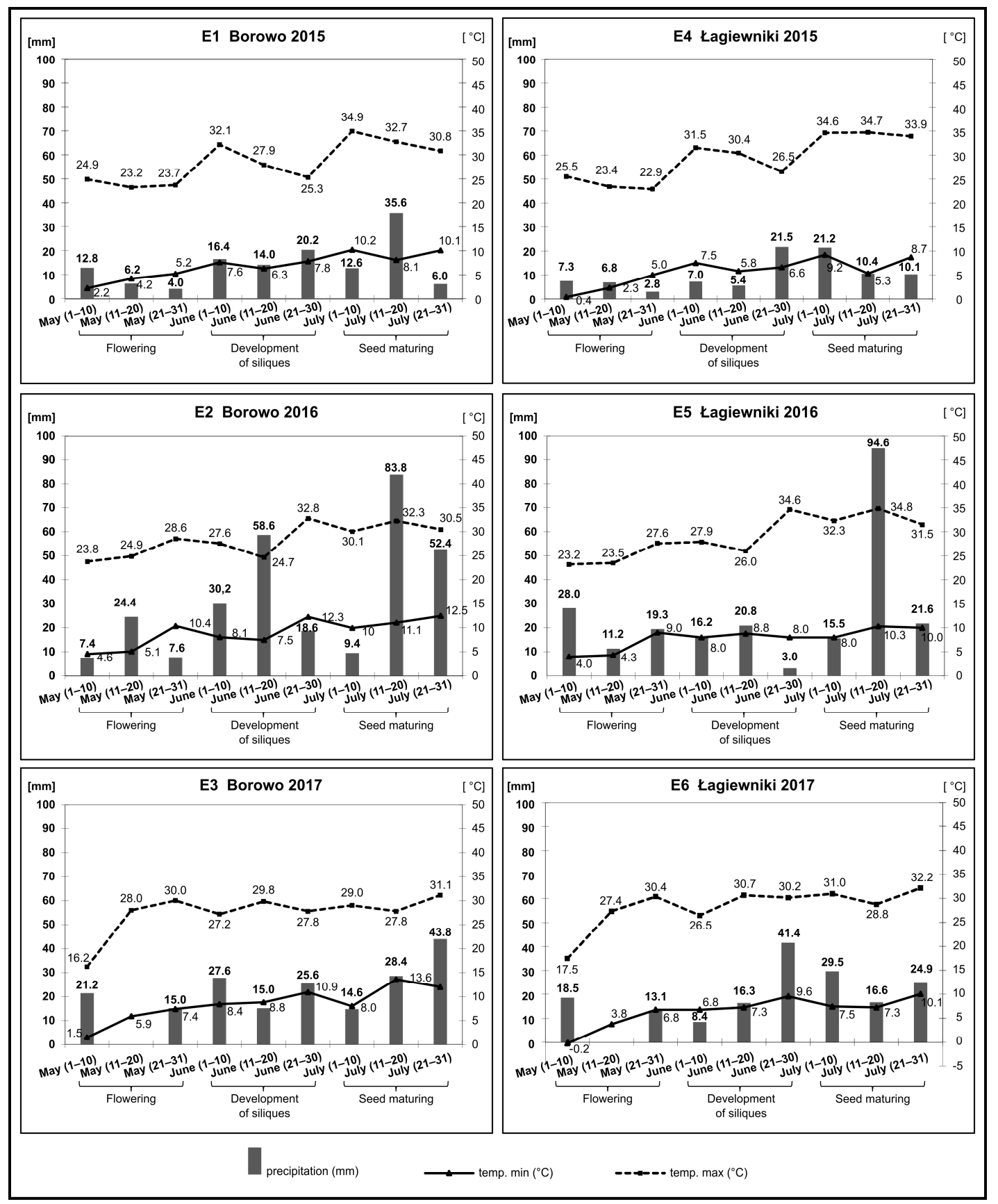

Figure 1. Weather conditions during flowering, development of siliques and seed maturing in 6 environments (E1-E6); dark grey bars, precipitation [mm]; black solid and dashed lines, minimum and maximum temperatures $\left[{ }^{\circ} \mathrm{C}\right]$, respectively. 


\subsection{Phenotyping the Seed Traits and Genotyping F1 Hybrids, Their Parental Components and HO and LL Breeding Lines}

Seed samples were collected from each plot in each replication for analyzing the oil content (\%), fatty acid composition (C18:1, C18:2, C18:3) (\%), total GLSs content ( $\mu$ mole $\mathrm{g}^{-1}$ of seeds) and protein content (\%). The oil content in seeds was estimated using the nuclear magnetic resonance method (Newport Instruments Ltd.). For determining the composition of fatty acids in seed oil, biochemical analysis was carried out using an Agilent Technologies 6890N Network GC System (Santa Clara, CA, USA). The total GLSs content was assessed via gas chromatographic analysis of the silyl derivatives of desulfoglucosinolates [29]. The content of protein was measured using near-infrared reflectance spectroscopy (NIRS) [30] and a minimum of $3 \mathrm{~g}$ of intact seeds was used and all the samples were scanned on the NIR Systems monochromator model 6500 (NIR Systems, Inc., Silver Spring, MD, USA).

Ogura F1 hybrid as well as the Rfo and CMS genotypes were monitored using a specific 'Multiplex SCAR' assay [31], whereas the HO mutant genotypes were determined with the use of an allele-specific CAPS marker [32,33] and the LL genotypes-using a functional SNaPshot assay [34].

\subsection{Statistical Analysis}

A two-way fixed-effect model was applied to determine the magnitude of the main effects of variation and their interaction on each trait. Simultaneously, least-squares means were produced for the AMMI model. The model first fitted the additive main effects of genotypes $(G)$ and environments (E), followed by the multiplicative effects of GE interaction by PCA. The environments were defined as the combinations of locations and years (E1: Borowo, 2015; E2: Borowo, 2016; E3: Borowo, 2017; E4: Łagiewniki, 2015; E5: Łagiewniki, 2016; E6: Łagiewniki, 2017). The AMMI model [19,35] was given by:

$$
y_{g e}=\mu+\alpha_{g}+\beta_{e}+\sum_{n=1}^{N} \lambda_{n} \gamma_{g n} \delta_{e n}+Q_{g e}
$$

where $y_{g e}$ is the trait mean of the genotype $\mathrm{g}$ in the environment $e, \mu$ is the grand mean, $\alpha_{\mathrm{g}}$ is the genotype mean deviation, $\beta_{e}$ is the environmental mean deviation, $N$ is the number of PCA axes retained in the adjusted model, $\lambda_{n}$ is the eigenvalue of the PCA axis $n, \gamma_{g n}$ is the genotype score for the PCA axis $n, \delta_{e n}$ is the eigenvector score for the PCA axis $n$ and $Q_{g e}$ is the residual which includes the AMMI noise and pooled experimental error. The expected distribution of $Q_{g e}$ was found to be normal. The AMMI stability values (ASVs) were used to compare the stability of genotypes as described by Purchase et al. [36]:

$$
\mathrm{ASV}=\sqrt{\left[\frac{S S_{\text {IPCA1 }}}{S S_{\text {IPCA2 }}}\left(\mathrm{IPCA}_{1}\right)\right]^{2}+\left(\mathrm{IPCA}_{2}\right)^{2}}
$$

where $S S$ is the sum of squares, IPCA $A_{1}\left(\mathrm{IPCA}_{2}\right)$ is the first (second) interaction principal component axis; the scores of IPCA $A_{1}$ and IPCA $A_{2}$ were the genotype scores in the AMMI model. The higher the IPCA score (which may be either negative or positive), the more specifically adopted a genotype is to certain environments. A lower ASV (AMMI stability value) score indicates a more stable genotype across the environments [37].

For each genotype, the genotype selection index (GSI) was calculated, which incorporates both, the mean of trait and the ASV index in a single criterion $\left(\mathrm{GSI}_{\mathrm{i}}\right)$, as follows [38]:

$$
\mathrm{GSI}_{\mathrm{i}}=\mathrm{RM}_{\mathrm{i}}+\mathrm{RA}_{\mathrm{i}}
$$

where $\mathrm{GSI}_{\mathrm{i}}$ is the genotype selection index for the $i$-th genotype, $\mathrm{RM}_{\mathrm{i}}$ is the rank of trait mean (from maximal to minimal for the content of oil, C18:1 and protein; from minimal to maximal for the content of C18:2 and C18:3 and the total GLS content) for the $i$-th genotype and $\mathrm{RA}_{\mathrm{i}}$ is the rank of ASV for the $i$-th genotype. Finally, the total genotype selection index (TGSI) [39] was calculated for each 
genotype as a sum of GSIs for all the six traits scored in this study. All the statistical analyses were conducted using the GenStat software package (v. 18).

\section{Results}

In this study, we analyzed six seed traits of 25 canola genotypes including oilseed rape cultivars and breeding lines of different genetic background, in multi-environmental field trials (two locations and three growing seasons). Mean values of the traits are presented in Table 2.

Table 2. Mean values of seed traits of 25 genotypes tested in field trials conducted in six environments. Oil, seed oil content (\%); C18:1, oleic acid (\%); C18:2, linoleic acid (\%); C18:3, linolenic acid (\%); GLS, total glucosinolates content ( $\mu$ mole $\mathrm{g}^{-1}$ of seeds); protein content (\%); TGSI, total genotype selection index.

\begin{tabular}{|c|c|c|c|c|c|c|c|c|}
\hline Code & Description & $\begin{array}{c}\text { Oil } \\
\text { Content }\end{array}$ & $\begin{array}{c}\text { C18:1 } \\
\text { Content }\end{array}$ & $\begin{array}{c}\text { C18:2 } \\
\text { Content }\end{array}$ & $\begin{array}{l}\text { C18:3 } \\
\text { Content }\end{array}$ & $\begin{array}{c}\text { Total GLSs } \\
\text { Content }\end{array}$ & $\begin{array}{l}\text { Protein } \\
\text { Content }\end{array}$ & TGSI \\
\hline G01 & Monolit & 46.72 & 65.02 & 18.22 & 8.92 & 12.27 & 20.98 & 158 \\
\hline G02 & Brendy & 46.09 & 65.03 & 18.45 & 9.34 & 16.80 & 21.35 & 155 \\
\hline G03 & Starter & 46.98 & 63.46 & 18.34 & 10.58 & 12.35 & 21.65 & 185 \\
\hline G04 & Mendel & 44.93 & 61.29 & 19.95 & 11.06 & 14.98 & 22.76 & 231 \\
\hline G05 & DH_D×C & 44.55 & 73.80 & 8.48 & 10.50 & 11.80 & 22.69 & 198 \\
\hline G06 & Z 114 & 45.53 & 59.95 & 22.86 & 9.93 & 9.71 & 22.98 & 182 \\
\hline G07 & Rfo_37 & 45.46 & 64.31 & 18.87 & 9.57 & 10.40 & 21.81 & 203 \\
\hline G08 & Rfo_38 & 45.36 & 73.50 & 10.50 & 8.45 & 10.55 & 22.59 & 145 \\
\hline G09 & Rfo_39 & 45.29 & 75.11 & 9.39 & 8.54 & 10.48 & 22.44 & 146 \\
\hline G10 & CMS_64 & 45.68 & 62.70 & 18.83 & 11.10 & 10.20 & 22.88 & 151 \\
\hline G11 & CMS_313 & 46.23 & 72.38 & 11.94 & 8.52 & 7.34 & 22.33 & 144 \\
\hline G12 & CMS_1612 & 47.84 & 72.79 & 12.02 & 8.15 & 6.99 & 21.05 & 115 \\
\hline G13 & HO_SS & 44.51 & 76.62 & 9.47 & 7.18 & 15.14 & 22.64 & 127 \\
\hline G14 & 00_SS & 45.85 & 74.57 & 9.98 & 8.00 & 8.18 & 22.01 & 124 \\
\hline G15 & HOLL_SS & 44.67 & 74.40 & 13.93 & 4.92 & 17.46 & 22.84 & 157 \\
\hline G16 & Polka & 45.05 & 75.60 & 9.66 & 8.12 & 15.83 & 22.57 & 150 \\
\hline G17 & HO_TP & 45.39 & 73.13 & 12.09 & 7.77 & 9.17 & 22.27 & 148 \\
\hline G18 & HO_TP_00 & 44.28 & 75.37 & 8.39 & 8.85 & 6.49 & 23.48 & 138 \\
\hline G19 & F1_952 & 46.14 & 76.55 & 8.66 & 7.97 & 10.25 & 22.35 & 100 \\
\hline G20 & $\mathrm{S} 43$ & 44.34 & 61.40 & 21.31 & 9.41 & 8.75 & 23.34 & 220 \\
\hline G21 & S1 & 45.70 & 63.46 & 19.34 & 9.93 & 10.35 & 22.02 & 173 \\
\hline G22 & Sherlock & 46.09 & 62.99 & 19.97 & 9.89 & 15.16 & 21.33 & 169 \\
\hline G23 & Zornyj & 45.58 & 62.29 & 19.51 & 10.58 & 20.16 & 22.82 & 173 \\
\hline G24 & F1_S2 & 46.55 & 72.37 & 12.30 & 8.16 & 6.09 & 22.09 & 131 \\
\hline \multirow[t]{4}{*}{ G25 } & F1_239 & 46.98 & 75.49 & 14.48 & 8.06 & 7.96 & 21.75 & 77 \\
\hline & Mean & 45.67 & 69.49 & 14.34 & 8.95 & 11.41 & 22.26 & \\
\hline & $\mathrm{LSD}_{0.05}$ & 1.24 & 1.15 & 1.06 & 0.48 & 1.31 & 0.79 & \\
\hline & $\mathrm{LSD}_{0.01}$ & 1.63 & 1.52 & 1.39 & 0.63 & 1.73 & 1.04 & \\
\hline
\end{tabular}

The analyzed genotypes revealed the typical for canola seed oil content of about $45-47 \%$, whereas the CMS_1612 breeding line (G12) was characterized by the highest content, of $47.84 \%$. Another CMS line-313 (G11), as well as the F1 hybrid genotypes-S2 and 239 (G24 and G25) and the cultivar Monolit (G01) revealed slightly lower but comparable oil content, referring to the calculated least significance level of 0.01 (Table 2.). The breeding line HO_TP_00 (G18) showed the lowest seed oil content (44.28\%). The cultivars Mendel (G03), Polka (G16) and Zornyj (G23), in addition to 6 recombinant breeding lines (G05, G06, G13, G14, G15, G17), three restorer lines (G07-09), one CMS (G10) and both semi-RS lines (G20 and 21) revealed slightly higher but comparable seed oil content (Table 2).

The content of the seed oil C18 mono- and polyunsaturated fatty acids was differentiated among the analyzed genotypes. The C18:1 content ranged from 59.95\% to $76.62 \%$. Each genotype, except of the Z114 breeding line (G06; 59.95\% of C18:1), showed more than the typical for canola $62 \%$ of C18:1. The high oleic mutant recombinant HO_SS (G13) breeding line was characterized by the highest content C18:1, 76.62\%. Similarly, the Rfo_39 line (G09), the high-oleic cultivar Polka (G16), the recombinant 
breeding line HO_TP_00 (G18) and the F1 hybrids_952 and 239 (G19 and G25) showed high C18:1 content, of more than $75 \%$. The C18:2 content ranged between $8.48 \%$, in the DH_D $\times C$ (G05) and $22.86 \%$, in the Z114 (G06) recombinant breeding lines. The C18:3 content ranged from $4.92 \%$ in the high oleic low linolenic mutant recombinant HOLL_SS (G15) breeding line to $11.06 \%$ in the cultivar Mendel (G04) (Table 2).

Each genotype revealed the typical for canola amount of GLS-less than $25 \mu$ mole $^{-1}$ of seeds; whereas almost all of them but two cultivars Brendy (G02) and Zornyj (G23), showed less than 15 umole $\mathrm{g}^{-1}$ of seeds (Table 2).

Seed protein content ranged from $20 \%$ to $24 \%$, whereas the HO_TP_00 (G18) breeding line revealed the highest content of $23.48 \%$ and the cultivar Monolit (G01)—the lowest one, of 20.98 (Table 2).

\subsection{Seed Oil Content}

Three sources of variation (G, E and GXE interaction), were found to be highly significant. In ANOVA, the sum of squares for the environment main effect represented $56.41 \%$ of the total variation in oil content. The differences between the genotypes explained $15.50 \%$ of the total variation in the content, while the effects of the G $\times E$ interaction explained $10.67 \%$ of the variation (Table 3). Values of the three principal components were also highly significant and jointly accounted for $88.18 \%$ of the whole effect on the variation in the oil content. The first principal component (IPCA 1) accounted for $41.43 \%$ of the variation caused by interaction, while the second (IPCA 2) and the third component (IPCA 3) accounted for $27.91 \%$ and $18.84 \%$, respectively. Among the tested genotypes, seed oil content varied from $42.32 \%$ in the DH_D $\times$ C breeding line (G05), in E2 (Borowo 2016) to $52.17 \%$ in the CMS_1612 (G12), in E4 (Łagiewniki 2015) throughout the six environments, with an average of 45.67\% (Table S2). In addition, the average oil content per environment varied from $43.91 \%$ in E2 to $49.25 \%$ in E4 (Table S2). The stability of the analyzed genotypes in six environments with respect to the seed oil content was visualized as a biplot (Figure 2). The DH_D $\times C$ (G05) and Z114 (G06) breeding lines interacted positively with the environments E3 (Borowo 2017) and E6 (Lagiewniki 2017) but negatively with the environment E4 (Eagiewniki 2015) (Figure 2), while the cultivar Monolit (G01) and the 00_SS (G14) and S43 breeding lines (G20) interacted positively with the environments E1 (Borowo 2015) and E2 (Borowo 2016) but negatively with E5 (Eagiewniki 2016). The analysis indicated that some genotypes exhibited a high level of adaptation; however, most of them showed a specific adaptability. The ASVs revealed variations in the stability of the seed oil content among the 25 genotypes tested (Table S2). The cultivar Zornyj (G23) and the Rfo_39 breeding line (G09) with an ASV of 0.136 and 0.180, respectively, were found to be the most stable, while the CMS 64 (G10) and DH_D $\times C$ (G05) with an ASV of 2.033 and 1.626, respectively, were the least stable (Table S2). The F1 hybrids 952 (G19) and 239 (G25) with a high average oil content (46.14\% and 46.98\%, respectively) and high ASVs ( 0.227 and 0.378 , respectively) had the best GSI of 10. The CMS_1612 breeding line (G12), as well as the cultivars Starter (G03), Sherlock (G22) and Zornyj (G23) revealed a high average seed oil content and high stability (Figure 2). They were also characterized by good genotype selection indexes GSIs of 12, 13, 14 and 14 , respectively (Table S2). 
Table 3. Mean squares (m.s.) from analysis of variance of main effects and interactions for tested traits in winter oilseed rape genotypes and variability explained (ve, in \%).

\begin{tabular}{|c|c|c|c|c|c|c|c|c|c|c|c|c|c|}
\hline \multirow{2}{*}{$\begin{array}{l}\text { Source of } \\
\text { Variation }\end{array}$} & \multirow{2}{*}{ d.f. } & \multicolumn{2}{|c|}{ Oil Content } & \multicolumn{2}{|c|}{ C18:1 Content } & \multicolumn{2}{|c|}{ C18:2 Content } & \multicolumn{2}{|c|}{ C18:3 Content } & \multicolumn{2}{|c|}{ Total GLSs Content } & \multicolumn{2}{|c|}{ Protein Content } \\
\hline & & m.s. & ve $(\%)$ & m.s. & ve $(\%)$ & m.s. & ve $(\%)$ & m.s. & ve $(\%)$ & m.s. & ve $(\%)$ & m.s. & ve (\%) \\
\hline Treatments & 149 & $16.8^{* * *}$ & 82.58 & $150 * * *$ & 96.30 & $101^{* * * *}$ & 96.02 & $9.36 * * *$ & 91.93 & $69.39 * * *$ & 92.79 & 7.01 *** & 81.25 \\
\hline Genotypes, G & 24 & $19.58^{* * *}$ & 15.50 & $868^{* * * *}$ & 89.97 & $574^{* * *}$ & 87.54 & $46.3^{* * *}$ & 73.29 & $337^{* * *}$ & 72.52 & $10.8^{* * *}$ & 20.15 \\
\hline Environments, E & 5 & $341.9^{* * *}$ & 56.41 & $77.5^{* * *}$ & 1.67 & $87.0^{* * *}$ & 2.76 & $31.4 * * *$ & 10.35 & $168^{* * *}$ & 7.56 & $130 * * *$ & 50.60 \\
\hline GE Interactions & 118 & $2.74^{* * *}$ & 10.67 & $9.1^{* * *}$ & 4.65 & $7.62 * * *$ & 5.71 & $1.07^{* * *}$ & 8.30 & $12.0^{* * *}$ & 12.72 & $1.14^{* * *}$ & 10.50 \\
\hline IPCA 1 & 28 & $4.78^{* * *}$ & 41.43 & $17.5^{* * *}$ & 45.45 & $12.46^{* * *}$ & 38.82 & $1.68^{* * *}$ & 37.49 & $24.5^{* * *}$ & 48.41 & $1.8^{* * *}$ & 37.23 \\
\hline IPCA 2 & 26 & 3.47 *** & 27.91 & 10.8 *** & 25.97 & $9.85^{* * *}$ & 28.48 & $1.33^{* * *}$ & 27.32 & $15.3^{* * *}$ & 28.16 & $1.35^{* * *}$ & 26.05 \\
\hline IPCA 3 & 24 & $2.54^{* * *}$ & 18.84 & $9.0^{* * *}$ & 20.13 & $10.02 * * *$ & 26.81 & $1.23^{* * *}$ & 23.43 & $7.66^{* * *}$ & 12.99 & $0.92 * *$ & 16.43 \\
\hline Residuals & 40 & 0.96 & & 2.3 & & 1.34 & & 0.37 & & $3.69 * * *$ & & 0.68 & \\
\hline Error & 378 & 1.14 & & 2.1 & & 1.56 & & 0.3 & & 1.86 & & 0.49 & \\
\hline
\end{tabular}

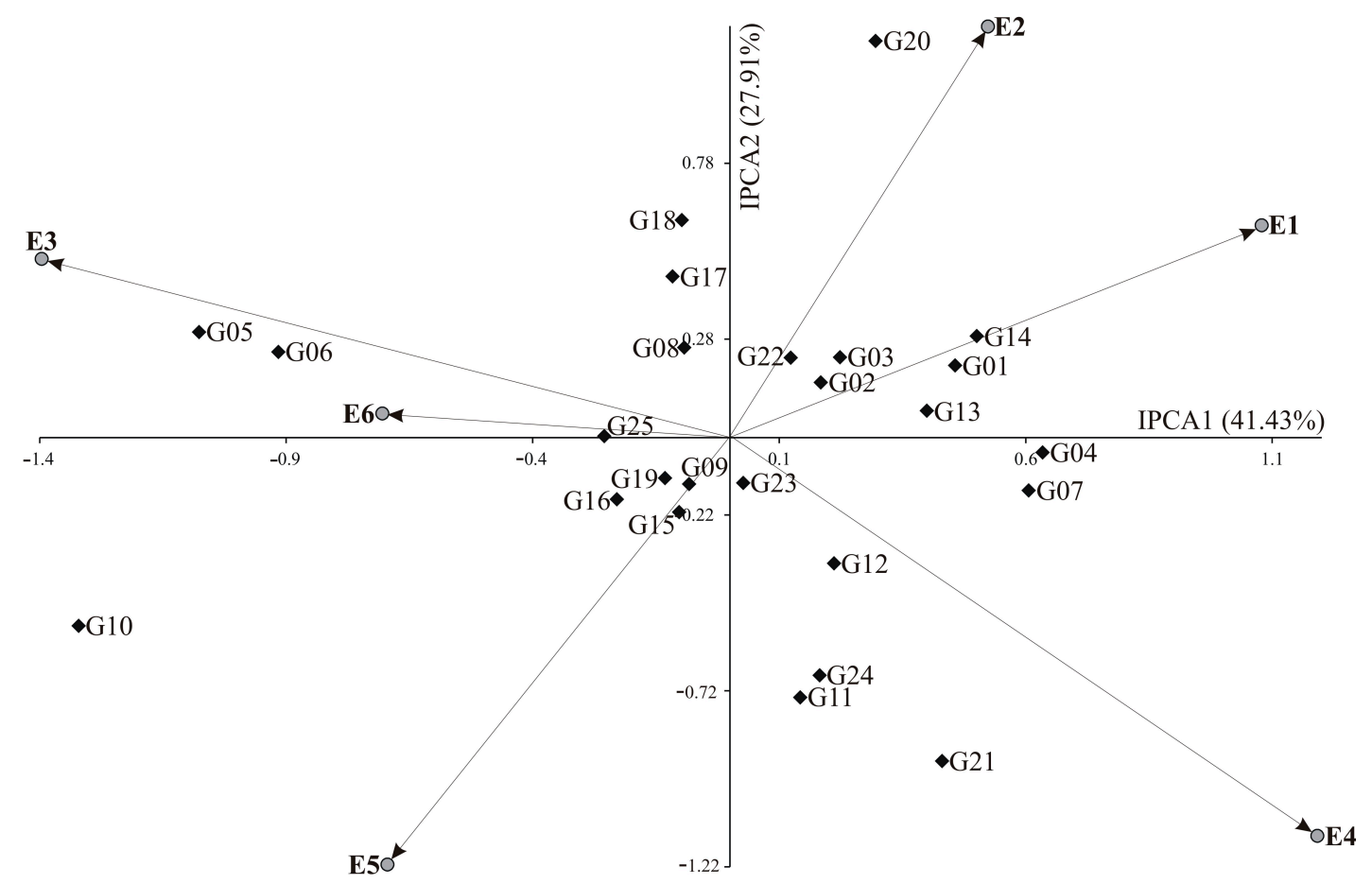

Figure 2. Biplot for genotype by environment interaction of oil content in 25 winter oilseed rape (B. napus) genotypes in six environments, showing the effects of primary and secondary components (IPCA 1 and IPCA 2, respectively) (E1-Borowo, 2015; E2-Borowo, 2016; E3-Borowo, 2017; E4—Łagiewniki, 2015; E5-Łagiewniki, 2016; E6- Łagiewniki, 2017).

\subsection{C18:1 Content}

The impact of the environment on C18:1 content in seed oil was low, however significant, representing only $1.67 \%$ of the variation. The differences between the genotypes explained $89.97 \%$ of the variation in the content of C18:1 in seed oil, while the effects of the GXE interaction explained $4.65 \%$ of the variation (Table 3). Values of the three principal components were also found to be highly significant and jointly accounted for $91.55 \%$ of the whole effect on the variation in the content of C18:1. IPCA 1 accounted for $45.45 \%$ of the variation caused by the interaction, while IPCA 2 and IPCA 3 accounted for $25.97 \%$ and $20.13 \%$ of the variation, respectively. Among the tested genotypes, C18:1 content varied from 55.48\% in the Z114 breeding line (G06), in E1 (Borowo 2015) to $78.15 \%$ in the HO_TP breeding line (G18), in E5 (Łagiewniki 2015) throughout the six environments, with an average of $69.34 \%$ (Table S3). In addition, the average content of C18:1 per environment varied from $68.33 \%$ in E1 (Borowo 2015) to 70.79\% in E6 (Eagiewniki 2017). The cultivar Polka (G16), as well as the DH_D $\times$ C (G05), Rfo_39 (G09) and HO_TP (G18) breeding lines interacted positively with the E5 
(Łagiewniki 2015) environment but negatively with E2 (Borowo 2016) (Figure 3). At the same time, the cultivars Monolit (G01), Brendy (G02) and also the Z114 (G06), CMS_64 (G10), S43 (G20) and S1 (G21) breeding lines interacted positively with the E3 (Borowo 2017) and E6 (Eagiewniki 2017) environments but negatively with E1 (Borowo 2015) and E4 (Łagiewniki 2015). The CMS_1612 breeding line (G12) and the cultivar Sherlock (G22) with the respective ASV scores of 0.184 and 0.350 were assessed as the most stable and the cultivar Mendel (G04) and the Rfo_37 breeding line (G07) with ASVs of 2.988 and 2.236, respectively, were the least stable (Table S3). The HO_SS breeding line (G13) with the highest average C18:1 content (76.62\%) and an ASV of 0.510 had the best GSI of 5 and the F1_239 hybrid (G25) with high C18:1 content $(75,49 \%)$ with an ASV of 0.539 had also good GSI of 9.

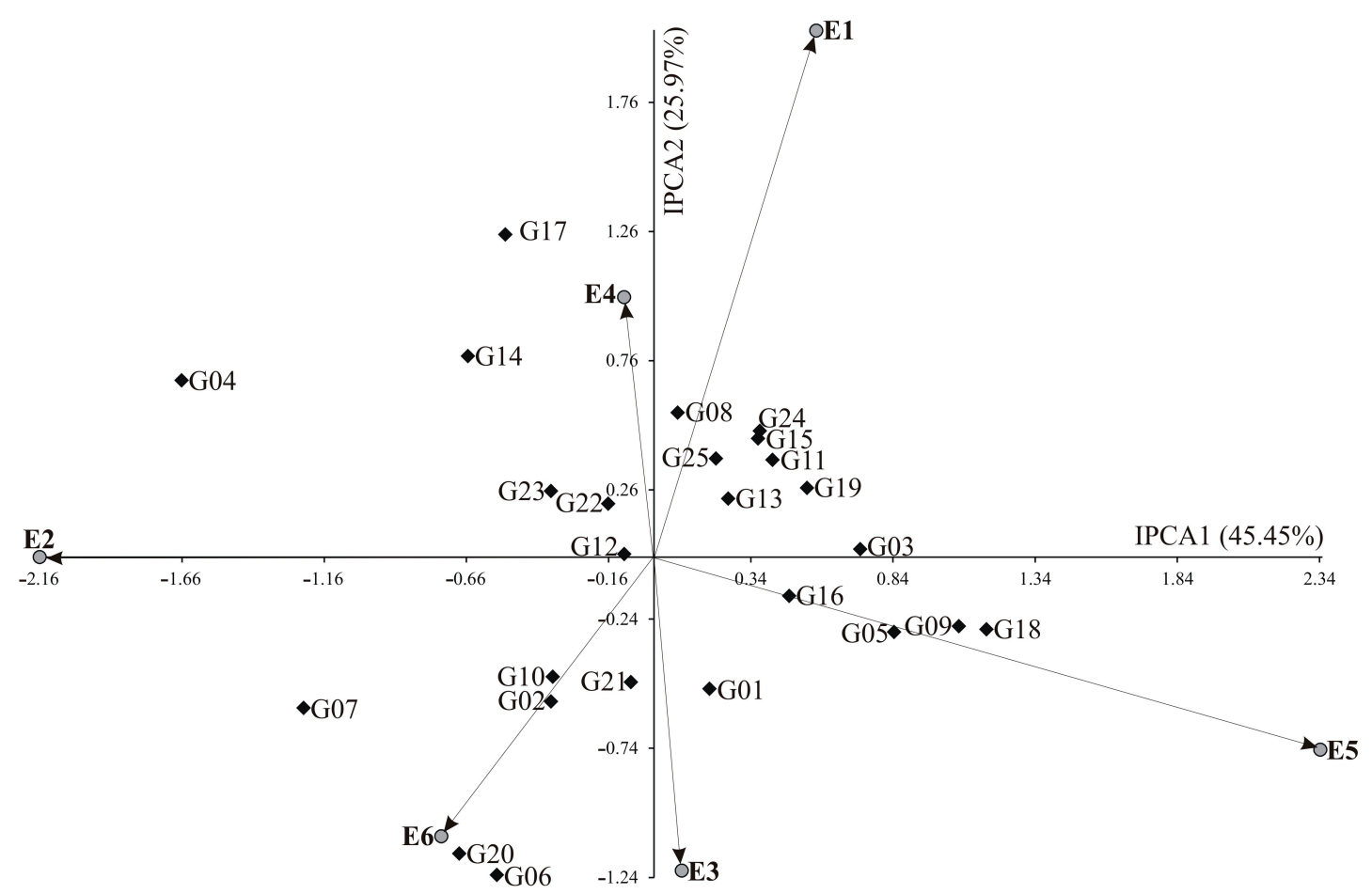

Figure 3. Biplot for genotype by environment interaction of $\mathrm{C} 18: 1$ content in 25 winter oilseed rape (B. napus) genotypes in six environments, showing the effects of primary and secondary components (IPCA 1 and IPCA 2, respectively) (E1-Borowo, 2015; E2-Borowo, 2016; E3-Borowo, 2017; E4—Łagiewniki, 2015; E5—Łagiewniki, 2016; E6—Łagiewniki, 2017).

\subsection{C18:2 Content}

The three sources of variation of C18:2 content were found to be highly significant. However, the genotype played the most important role in determination of this trait. The environment main effect represented only $2.76 \%$ of the total variation. The differences between the genotypes explained $87.54 \%$ of the total variation in the content of $\mathrm{C} 18: 2$, while the effects of $\mathrm{G} \times \mathrm{E}$ interaction explained $5.71 \%$ of the variation (Table 3). Values of the first three principal components were also found to be highly significant and jointly accounted for $94.11 \%$ of the whole effect on the variation in the content of C18:2. IPCA 1 accounted for $38.82 \%$ of the variation caused by the interaction, while IPCA 2 and IPCA 3 accounted for $28.48 \%$ and $26.81 \%$ of the variation, respectively. In the tested genotypes, the content of C18:2 varied from 6.35\% in the HO_TP breeding line (G18), in E5 (Eagiewniki 2015) to $25.82 \%$ in the Z114 breeding line (G06), in E1 (Borowo 2015) throughout the six environments, with an average of $14.48 \%$ (Table S4). In addition, the average C18:2 content per environments varied from 13.39\% in E6 (Eagiewniki 2017) to 15.70\% in E3 (Borowo 2015). The stability of the tested genotypes with respect to C18:2 content was visualized as a biplot (Figure 4). The tested genotypes interacted differently with the environments. The cultivar Monolit (G01) and two F1 hybrids, S2 (G24) and 
239 (G25) interacted positively with the E6 (Eagiewniki 2017) environment but negatively with E5 (Łagiewniki 2016) (Figure 4). The Rfo_37 (G07) and HOLL_SS (G15) breeding lines, as well as the cultivar Sherlock (G22) and Zornyj (G23) interacted positively with the E3 (Borowo 2017) environment but negatively with E2 (Borowo 2016) and E4 (Łagiewniki 2015). The ASVs revealed the variations in the stability of C18:2 content among the genotypes (Table S4). The CMS_1612 breeding line (G12) and the cultivar Monolit (G01) with an ASV of 0.116 and 0.287, respectively, were identified to be the most stable, while the S43 breeding line (G20) and the cultivar Mendel (G04) revealing an ASV index of 2.060 and 1.890, respectively, were the least stable (Table S4). The F1_239 hybrid (G25) with a low average C18:2 content $(9.50 \%)$ and an ASV of 0.364 had the best GSI of 10. The CMS_1612 (G12), HO_SS (G13) and DH_D $\times$ C (G05) breeding lines, the F1_952 hybrid (G19) and the cultivar Monolit (G01) had a low average $\mathrm{C} 18: 2$ content and showed high stability (Figure 4). Furthermore, those genotypes revealed good GSIs of 12, 13, 18, 18 and 17, respectively (Table S4).

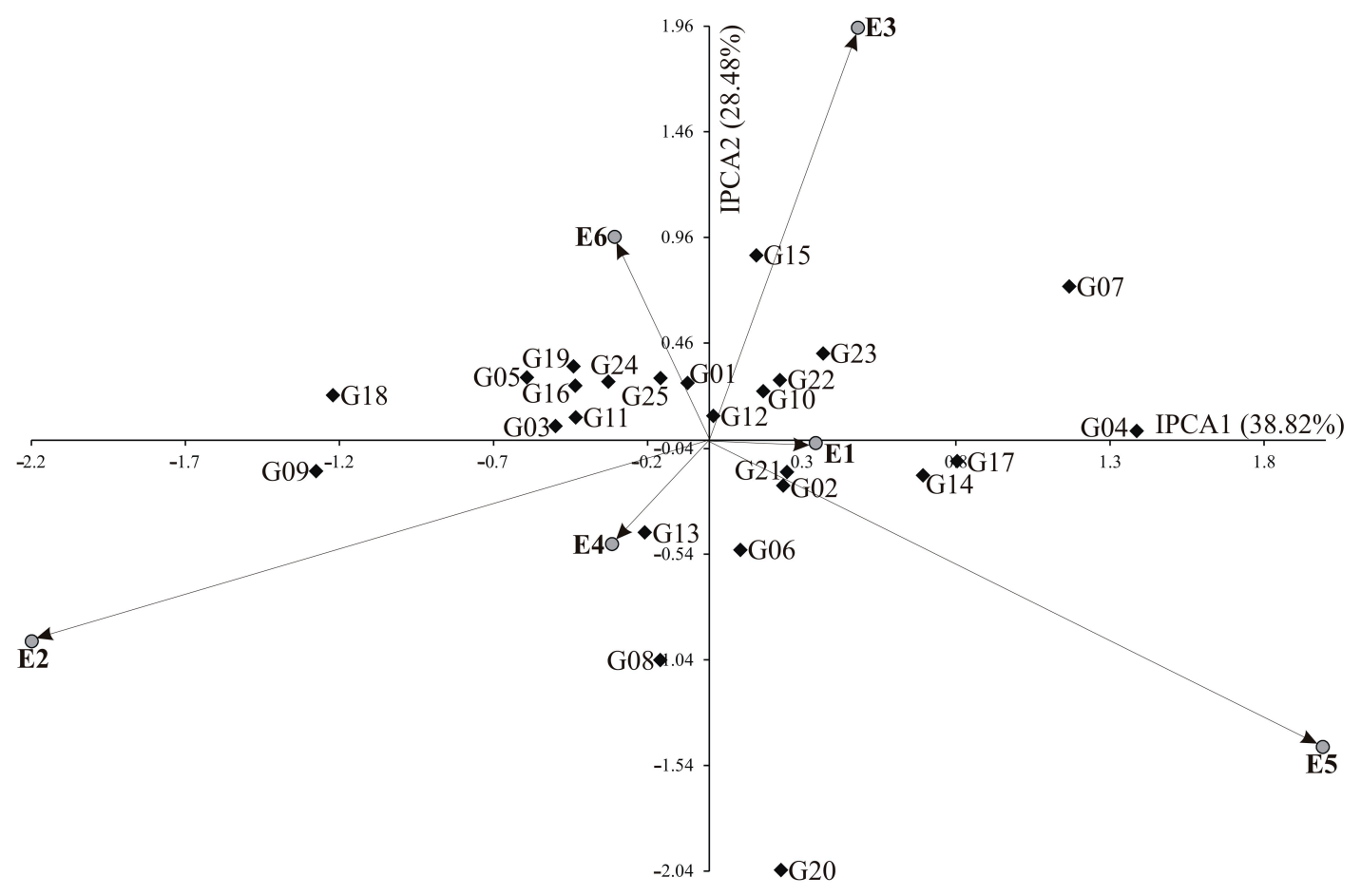

Figure 4. Biplot for genotype by environment interaction of C18:2 content in 25 winter oilseed rape (B. napus) genotypes in six environments, showing the effects of primary and secondary components (IPCA 1 and IPCA 2, respectively) (E1-Borowo, 2015; E2-Borowo, 2016; E3-Borowo, 2017; E4—Łagiewniki, 2015; E5—Łagiewniki, 2016; E6—Łagiewniki, 2017).

\subsection{C18:3 Content}

The three sources of variation were found to be highly significant with respect to the C18:3 content, whereas the $G$ parameter was the most meaningful. In ANOVA, the sum of squares for the environment main effect represented $10.35 \%$ of the total variation in the $\mathrm{C} 18: 3$ content, while the differences between the genotypes explained $73.29 \%$ of the total variation. At the same time, the effects of the $\mathrm{G} \times \mathrm{E}$ interaction explained $8.30 \%$ of the variation (Table 3). Values of the three principal components were also found to be highly significant and jointly accounted for $88.24 \%$ of the whole effect on the variation in the content of linolenic acid. IPCA 1 accounted for $37.49 \%$ of the variation caused by the interaction, while IPCA 2 and IPCA 3 accounted for $27.32 \%$ and $23.43 \%$ of the variation, respectively. Among the tested genotypes, the C18:3 content varied from $4.00 \%$ in the HOLL_SS breeding line (G15), in E5 (Eagiewniki 2016) to 12.00\% in the CMS_64 breeding line (G10) in E4 (Eagiewniki 2015) throughout the six environments, with an average of $8.94 \%$ (Table S5). The genotype G10 had the highest average 
content of $\mathrm{C} 18: 3(11.10 \%)$, while the genotype G15 had the lowest content $(4.92 \%)$. The average content per environments also varied from $8.44 \%$ in E5 to $9.74 \%$ in E1. The stability of the tested genotypes with respect to C18:3 was visualized as a biplot (Figure 5). The cultivars Monolit (G01) and Starter (G03), as well as the DH_D ×C (G05), CMS_313 (G11), CMS_1612 (G12) and 00_SS (G14) breeding lines interacted positively with the environments E2 (Borowo 2016) and E5 (Eagiewniki 2016) but negatively with E1 (Borowo 2015), E3 (Borowo 2017), E4 (Łagiewniki 2015) and E6 (Łagiewniki 2017) (Figure 5). The Rfo_37 (G07), HO_TP (G17) and HO_TP_00 (G18) interacted positively with the environments E1 (Borowo 2015) and E4 (Łagiewniki 2015), while the cultivars Mendel (G04), Polka (G16) and Zornyj (G23), as well as the F1_S2 hybrid (G24) and the Z114 breeding line (G06) interacted positively with E3 (Borowo 2017) and E6 (Eagiewniki 2017). The CMS_64 (G10), Sherlock (G22), Brendy (G02), CMS_1612 (G12), Monolit (G01), F1_952 (G19) and Polka (G16) having an ASV of 0.123, 0.180, 0.210, $0.257,0.279,0.279$ and 0.286 , respectively, were found to be the most stable, while the HOLL_SS (G15), S1 (G21) and S_43 (G20) breeding lines with an ASV of 1.681, 1.090 and 0.911, respectively, were the least stable (Table S5). The genotype G19 revealing the lowered average content of C18:3 of 7.97\% and with the ASV index of 0.279 had the best GSI of 10 .

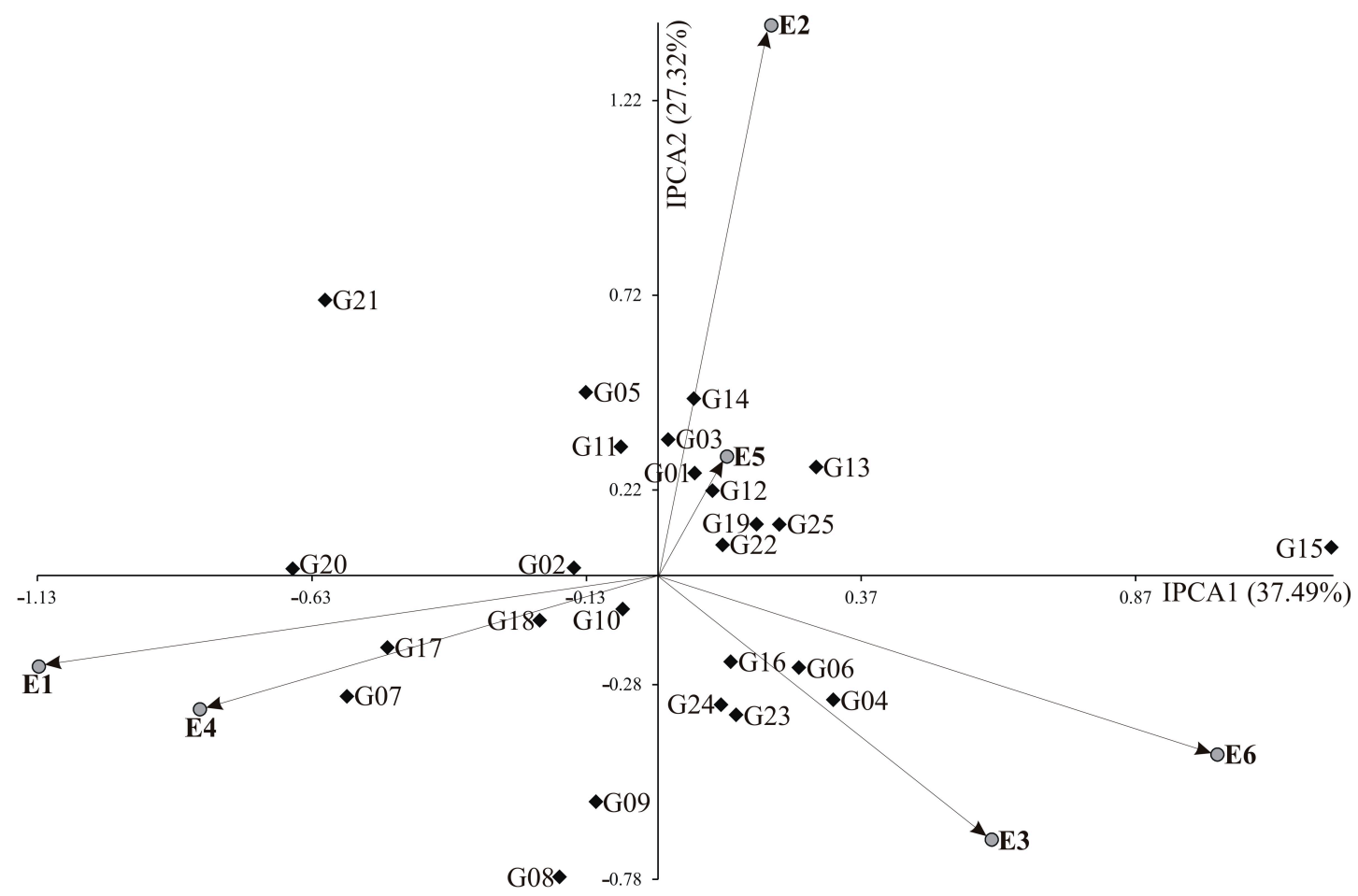

Figure 5. Biplot for genotype by environment interaction of $\mathrm{C} 18: 3$ content in 25 winter oilseed rape (B. napus) genotypes in six environments, showing the effects of primary and secondary components (IPCA 1 and IPCA 2, respectively) (E1-Borowo, 2015; E2-Borowo, 2016; E3-Borowo, 2017; E4—Łagiewniki, 2015; E5—Łagiewniki, 2016; E6—Łagiewniki, 2017).

\subsection{Total GLS Content}

In ANOVA, the sum of squares for the genotype main effect represented $72.52 \%$ of the total variation of the GLSs content indicating that $\mathrm{G}$ had the highest effect on that seed trait. The differences between the environments explained $7.56 \%$ of the total variation in the content, while the effects of the G $\times$ E interaction explained $12.72 \%$ of the variation (Table 3). The values of the three principal components were also found to be highly significant. The three principal components of the $\mathrm{G} \times \mathrm{E}$ interaction jointly accounted for $89.56 \%$ of the whole effect on the variation in the total GLSs content. IPCA 1 accounted for $48.41 \%$ of the variation caused by the interaction, while IPCA 2 and IPCA 3 accounted for $28.16 \%$ and $12.99 \%$ of the variation, respectively (Figure 6). Total GLS content of the 
analyzed genotypes varied from 4.40 in the HO_TP_00 breeding line (G18), in E4 (Łagiewniki 2015) to $26.93 \mu$ mole $\mathrm{g}^{-1}$ of seeds in the cultivar Zornyj (G23), in E6 (Lagiewniki 2017) throughout the six environments, with an average of $11.40 \mu$ mole $^{-1}$ of seeds (Table S6). In addition, the average total GLSs content per environment varied from $9.97 \mu$ mole $^{-1}$ of seeds in E4 (Eagiewniki 2015) and E5 (Łagiewniki 2016)to $13.26 \mu$ mole g $^{-1}$ of seeds in E3 (Borowo 2017). The stability of the tested genotypes with respect to the total GLSs content was visualized as a biplot (Figure 6). The cultivar Polka (G16) and Sherlock (G22) interacted positively with the environments E1 (Borowo 2015) and E4 (Łagiewniki 2015) (Figure 6), while the S1 breeding line (G21) and the cultivar Zornyj (G23) interacted positively with E3 (Borowo 2017) and E6 (Łagiewniki 2017) but negatively with E2 (Borowo 2016). The 00_SS breeding line (G14), as well as the F1 hybrids, 239 (G25) and S2 (G24) with an ASV of 0.119, 0.165 and 0.269, respectively, were found to be the most stable. The cultivar Zornyj (G23) and the DH_D $\times$ C breeding line (G05) with an ASV of 4.897 and 3.293, respectively, were the least stable (Table S6). The F1_S2 hybrid (G24), the 00_SS breeding line (G14) and the F1_239 hybrid (G25) with a low average total GLS content revealed good GSIs of 4, 7 and 7, respectively, while the cultivar Zornyj (G23) had the worst GSI of 50 .

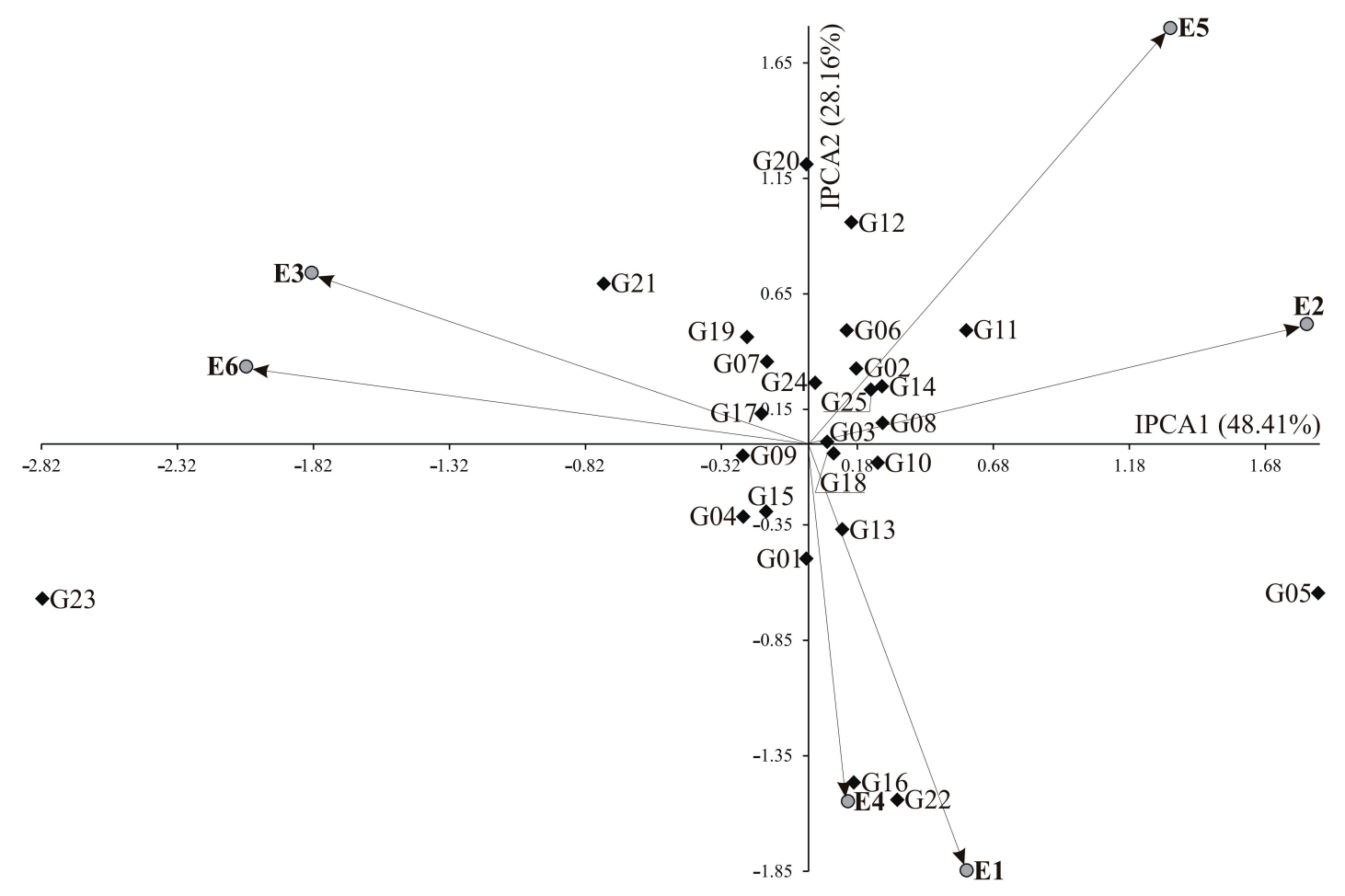

Figure 6. Biplot for genotype by environment interaction of total GLSs content in 25 winter oilseed rape (B. napus) genotypes in six environments, showing the effects of primary and secondary components (IPCA 1 and IPCA 2, respectively) (E1-Borowo, 2015; E2-Borowo, 2016; E3-Borowo, 2017; E4-Łagiewniki, 2015; E5—-Lagiewniki, 2016; E6—-_agiewniki, 2017).

\subsection{Protein Content}

The three sources of variation for the protein content were found to be highly significant. In the contrary to the previous traits, protein content was highly modified by environment. In ANOVA, the environment main effect represented $50.60 \%$ of the total variation, while the differences between the genotypes explained $20.15 \%$ of the total variation and the effects of the G×E interaction explained $10.50 \%$ of the variation (Table 3). Values of the three principal components were also found to be highly significant and jointly accounted for $79.71 \%$ of the whole effect on the variation in the protein content. IPCA 1 accounted for $37.23 \%$ of the variation caused by the interaction, while IPCA 2 and 
IPCA 3 accounted for $26.05 \%$ and $16.43 \%$ of the variation, respectively. Among the tested genotypes, the protein content varied from $18.97 \%$ in the cultivar Monolit (G01) in E2 (Borowo2016) to $24.93 \%$ in the HO_TP breeding line (G18) in E6 (Lagiewniki 2017) throughout the six environments, with an average of $22.28 \%$ (Table S7). In addition, the average protein content per environment varied from $20.82 \%$ in E4 (Eagiewniki 2015) to 23.70\% in E3 (Borowo 2017). As shown the Figure 7, the cultivar Monolit (G01), as well as the Rfo_37 (G07), Rfo_38 (G08) and CMS_1612 (G12) breeding line interacted positively with the environments E3 (Borowo 2017) and E6 (Eagiewniki 2017) but negatively with E2 (Borowo 2016). The cultivar Mendel (G04), as well as the HO_SS (G13), HOLL_SS (G15), HO_TP (G17) and HO_TP_00 (G18) interacted positively with E5 (Lagiewniki 2016) but negatively with E1 (Borowo 2015). At the same time, the Rfo_38 (G09) and S43 (G20) breeding line, as well as the F1_239 hybrid (G25) interacted positively with E4 (Łagiewniki 2017). The 00_SS (G14), S1 (G21) and Z114 (G06) with an ASV of 0.126, 0.140 and 0.186 , respectively, were found to be the most stable, while the cultivars Monolit (G01) and Starter (G03) with an ASV of 1.337 and 1.024, respectively, were the least stable (Table S7). The Z114 breeding line (G06) with a high average protein content (22.98\%) and an ASV of 0.186 had the best GSI (6), while the cultivar Monolit (G01) had the worst GSI (50).

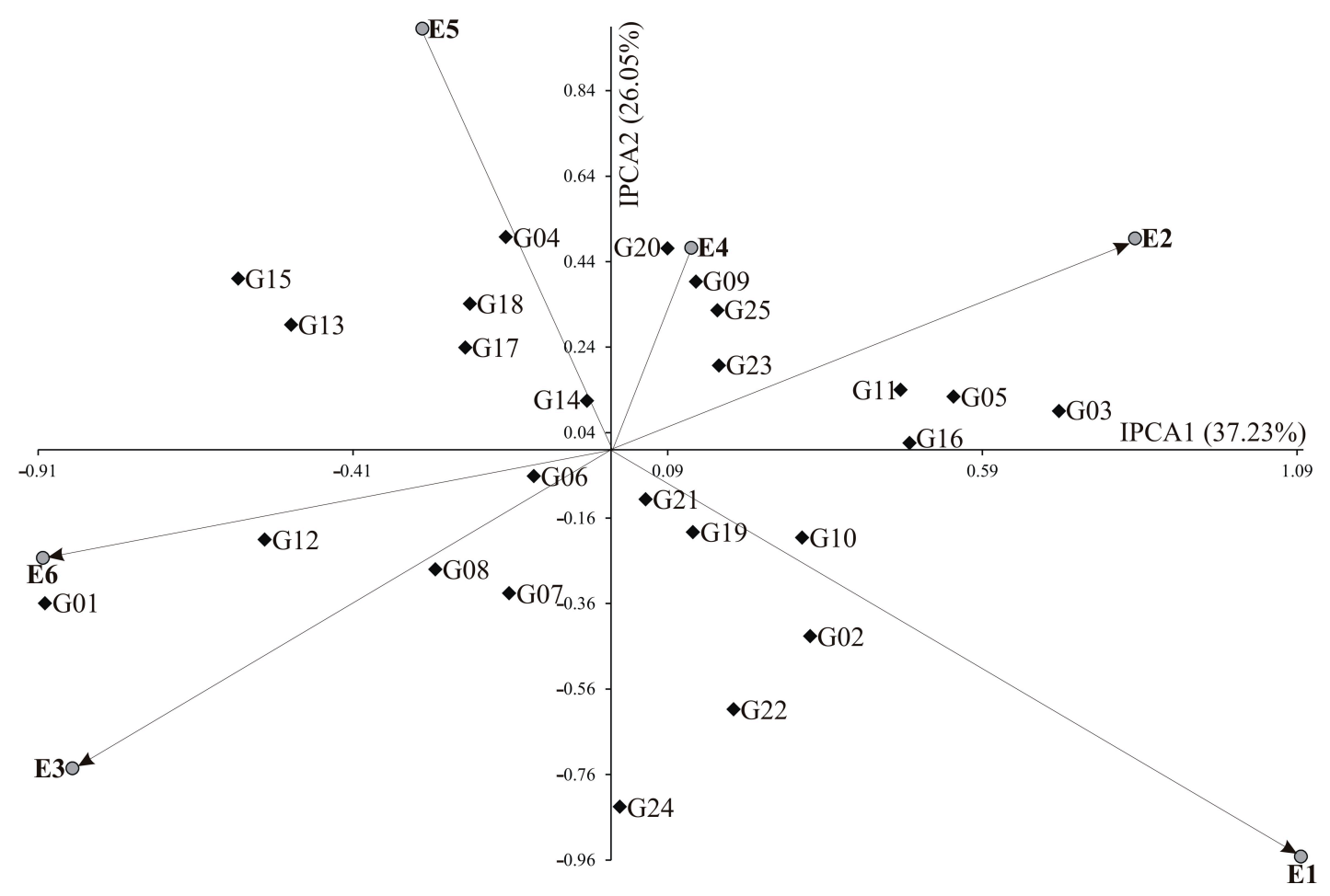

Figure 7. Biplot for genotype by environment interaction of protein content in 25 winter oilseed rape (B. napus) genotypes in six environments, showing the effects of primary and secondary components (IPCA 1 and IPCA 2, respectively) (E1-Borowo, 2015; E2-Borowo, 2016; E3-Borowo, 2017; E4-Łagiewniki, 2015; E5—Łagiewniki, 2016; E6—-Lagiewniki, 2017).

\section{Discussion}

Agronomic and seed traits of Brassica species, especially of B. napus, have been of high importance for plant breeders for several decades. Friedt and Lühs [40] reported that one of the most important objectives of oilseed rape breeding programs is to achieve genetic modification of seed oil quality by changing the proportion of fatty acids according to either nutritional or industrial requirements. The authors also demonstrated that the value of oilseed rape as a component of food and forage can be further improved by enhancing desirable traits (e.g., oil content and fatty acid composition) and reducing undesired characteristics (e.g., fiber content or other antinutritional compounds). Quantitative traits, as oil and protein content, as well as the composition of fatty acids in seed oil, in addition to the GLS 
content in seed meal are determined by multiple genes and their expression may depend on changing environment conditions. Therefore, some phenotype changes my occur as a result of different responses of particular genotypes to the environments conditions [39,41]. The most influencing environment factors are: the temperature, the availability of water and the agronomic conditions including soil type and $\mathrm{pH}$ value $[7,42,43]$. It was the case in our results showing that the examined six seed traits were significantly affected by environment.

The soil types and weather conditions differed between the two tested locations in which the field trials were conducted in Borowo and Łagiewniki. The types of soil were classified as light, loamy sand (LS) in Borowo (E1-E3) and as "medium" or "heavy soil"—sandy loam (SL) and sandy clay loam (SCL) in Łagiewniki (E4-E6). Soil in Łagiewniki is rich in fine clay particles. Among the tested environments (E1-E6), the highest soil water accumulation has been observed in Łagiewniki in 2015 (E4) and 2016 (E5) and such conditions could have contributed to higher seed oil and lower GLS content, as compared to the other environments. The $\mathrm{pH}$ values of those soils were slightly acidic, varying from 6.0 (E1, E2, E3) to 6.2 (E4 and E6). Timing and rate of nitrogen fertilization were the same in each field trial. At the same time, weather conditions, that is, temperature and rainfall varied among the six environments. For example, in Borowo and in Łagiewniki in 2015 (E1 and E4) and in Borowo in 2017 (E3), there was a severe lack of rainfall in May—during the flowering period of WOSR (Figure 1). In July 2016 during seed maturation period, there was an extremely intensive rainfall in both locations (E2 and E5); moreover, heavy storm delayed the harvest. However, those weather conditions did not substantially influence the mean values of the seed traits analyzed in particular environments. In this study, the soil water availability depending on the type of soil was the source of variation.

We found that the $G$ and $G \times E$ interaction variances were significant for all traits of the analyzed 25 WOSR genotypes. Genotype had a significant impact on the C18:1, C18:2 and C18:3 fatty acids and the total GLS content in both locations. At the same time, the main effects of both, E and GXE interaction mostly influenced seed oil and seed protein content. Bocianowski et al. [39] reported the same results for quality traits in their study on 23 interspecific cross-derived Brassica lines in Poland. In our study, a strong environmental, especially type of soil effect on average oil content was observed in both locations during the three growing seasons. For example, higher oil content was observed in Łagiewniki with potentially fertile soil (E4-E6) than in Borowo (E1-E3). Our results are consistent with a significant environmental contribution to the variation in oil content observed by Zhao et al. [44], who conducted experiments with 282 lines in differentiated locations, in China and Germany. Similar results were obtained by Delourme et al. [45] in field trials and QTL analyzes using two DH populations of oilseed rape in different environments, in France. Nowosad et al. [37] also reported that the G and E main effects as well as $\mathrm{G} \times \mathrm{E}$ interaction had the strongest effects on oil content in western Poland. Friedt and Snowdon [7] showed that the majority of seed components significantly depended on both genetic and environmental factors, whereas temperature, water availability and nutrient supply were the most influential factors in their experiments in Germany. Also, Liersch et al. [46] got similar results from their field trials in Poland. Moreover, significant influence of environmental factors, as temperature and rainfall, on seed quality traits were previously reported from experiments on canola in Australia and China [47-49]. Also, the previous study on sunflower in the USA showed that the seed oil content was affected by environmental conditions - temperature and radiation during seed maturation [50].

In this study, genotypic variability regarding the seed oil fatty acids composition was revealed among the analyzed 25 genotypes, in the six environments. The $\mathrm{G}$ effect explained $89.97 \%$ of variation in C18:1 content, $87.54 \%$ in C18:2 and $73.29 \%$ in C18:3 content. At the same time, GXE interaction revealed a small but statistically significant influence of $E$ on the seed oil fatty acid composition in the analyzed canola genotypes. Spasibionek et al. [14] also reported on the GXE interaction effect, while analyzing their new canola genotypes characterized by differentiated C18 fatty acids composition in seed oil in field experiments in western Poland. In our study, the weather conditions-temperature and precipitation varied during the flowering, development of siliques and seed maturing periods of the analyzed three growing seasons. However, it did not significantly influence the mean values of 
mono- (C18:1) and polyunsaturated (C18:2, C18:3) fatty acids content in seed oil. Different reaction of the 25 genotypes among environments may have resulted from the origin of genotype and different genetic background as well as the slight impact of $\mathrm{E}$.

In our study, the analyzed 25 genotypes varied in the total GLS content, whereas its mean value ranged from $9.97 \mu$ mole $\mathrm{g}^{-1}$ of seeds in Łagiewniki (E4, E5) to $13.26 \mu$ mole $\mathrm{g}^{-1}$ of seeds in Borowo (E3). The trait is determined by multiple genes that cause variability in the performance of genotypes and the differences in their response to the environment $[15,51,52]$. In this study, statistical ANOVA showed differences in total GLS content due to G, E and GXE interaction. The type of soil determining the availability of water could contribute to the lower GLS content in particular genotypes in Łagiewniki, as compared to Borowo. Padilla et al. [53] indicated significant differences in total GLSs content related to sites, varieties and site $\times$ variety interaction in 113 varieties of Brassica rapa. Similar results were reported by Niemann et al. [5] in their study on 25 Brassica lines of different origin. Moreover, several authors have reported that variation in the content of GLS in Brassica plants can be attributed to genetic and environmental factors, including plant age, temperature, water stress and soil type [54-56]. Furthermore, achieving high protein content in seeds and low detergent fiber is an important goal of oilseed rape breeders. In this study, significant differences $(p<0.001)$ were found in the seed protein content due to G, E and GXE interactions. Chen et al. [57] and Würschum et al. [42] also reported significant genotype $\times$ location interactions for protein content in different oilseed rape collections.

Complexity of the quality traits is reflected by different responses of genotypes to varying environmental conditions during development. Many breeders have been attempting to understand the importance of $\mathrm{G} \times \mathrm{E}$ interactions by collecting and analyzing phenotypic data from the long-term breeding programs $[16,17]$. Multi-environmental trials are conducted to determine the sites representing the target environment and to identify the genotypes best suited for specific environmental conditions, as well as to find the superior lines and genotypes that can be recommended to breeders [58]. Yan and Hunt [59] indicated that data collected from such trials can be used for precise estimation of genotype value and yield stability.

In this work, we used the AMMI model to study the interaction effect of G, E and GXE in each environment and to identify the genotypes best suited for specific environmental conditions. The model has been widely used in previous studies on Brassica and other crop plant species [37,39,60,61]. In our study, the analysis revealed significant GXE interaction for all the investigated traits and the ASVs indicated genotype stability.

\section{Conclusions}

In this study we observed statistically significant impact of $E$ on both, the seed oil and protein content among the analyzed 25 WOSR genotypes.

The C18:1, C18:2 and C18:3 fatty acids content was determined mostly by $G$ and to a lesser but statistically significant, extent by $\mathrm{E}$ as well as by the $\mathrm{G} \times \mathrm{E}$ interaction.

The use of the AMMI model analysis enabled us to determine four highly stable genotypes among the tested environments: two F1 hybrids-the F1 952 (G19) and F1 239 (G25), as well as the CMS_1612 (G12) breeding line and the HO_SS (G13) high oleic mutant recombinant line. In addition, those genotypes were characterized by optimal mean values of the analyzed 6 seed traits, except of the low seed oil content of the HO_SS breeding line (G13). Moreover, the genotypes G19, 25, 12 and 13 revealed superior respective TGSI of 77,100, 115 and 127, thus making a valuable source of starting materials in our forthcoming breeding programs.

Supplementary Materials: The following are available online at http://www.mdpi.com/2077-0472/10/12/607/s1; Table S1: Summary of the phenotypic data of seed traits assessed in collection of 25 WOSR genotypes across environments, Table S2: Average oil content (\%), for genotypes and environments, principal component analysis values (IPCAg1, IPCAg2), AMMI stability value (ASV), rank of the AMMI stability value (RA), rank of trait mean (RM, from maximal to minimal) and genotype selection index (GSI) of tested winter oilseed rape lines, Table S3: Average C18:1 (\%), for genotypes and environments, principal component analysis values (IPCAg1, IPCAg2), 
AMMI stability value (ASV), rank of the AMMI stability value (RA), rank of trait mean (RM, from maximal to minimal) and genotype selection index (GSI) of tested winter oilseed rape lines, Table S4: Average C18:2 (\%), for genotypes and environments, principal component analysis values (IPCAg1, IPCAg2), AMMI stability value (ASV), rank of the AMMI stability value (RA), rank of trait mean (RM, from minimal to maximal) and genotype selection index (GSI) of tested winter oilseed rape lines, Table S5: Average C18:3 (\%), for genotypes and environments, principal component analysis values (IPCAg1, IPCAg2), AMMI stability value (ASV), rank of the AMMI stability value (RA), rank of trait mean (RM, from minimal to maximal) and genotype selection index (GSI) of tested winter oilseed rape lines, Table S6: Average total GLS content ( $\mu$ mole g-1 of seeds), for genotypes and environments, principal component analysis values (IPCAg1, IPCAg2), AMMI stability value (ASV), rank of the AMMI stability value (RA), rank of trait mean (RM, from minimal to maximal) and genotype selection index (GSI) of tested winter oilseed rape lines, Table S7: Average protein content (\%), for genotypes and environments, principal component analysis values (IPCAg1, IPCAg2), AMMI stability value (ASV), rank of the AMMI stability value (RA), rank of trait mean (RM, from maximal to minimal) and genotype selection index (GSI) of tested winter oilseed rape lines, Table S8: Meteorological conditions in Borowo and Łagiewniki during the growing season of winter oilseed rape in 2015, 2016 and 2017, Figure S1: Mean monthly air temperature and cumulative precipitation during each growing season of experimentation and over an extended period in Borowo (E1-E3) and Łagiewniki (E4-E6).

Author Contributions: Conceptualization, A.L. and J.B.; methodology, A.L. and S.S.; software, J.B., K.N. and F.W.; validation, A.L., J.B. and I.B.-B.; formal analysis, A.L., J.B. and K.N.; investigation, A.L., J.B., K.M., M.M. and I.B.-B.; resources, A.L., S.S., L.S., T.C.-T., K.S.; data curation, A.L. and J.B.; writing-original draft preparation, A.L., J.B., and K.M.; writing-review and editing, A.L., J.B., K.M. and I.B.-B.; visualization, J.B., K.N. and F.W.; supervision, A.L., J.B.; project administration, I.B.-B., K.M. and A.L; funding acquisition, I.B.B. and K.M. All authors have read and agreed to the published version of the manuscript.

Funding: This research was funded by the Polish Ministry of Agriculture and Rural Development (https: //www.gov.pl/web/rolnictwo), program titled "Biological Progress in Plant Production, 2014-2020," task no. 48.

Acknowledgments: The authors would like to thank the colleagues at IHAR: Krzysztof Michalski for seed trait biochemical analyzes, Wiesława Popławska for F1 hybrids and their parental genotypes development and breeding, as well as Katarzyna Śliwińska and Jacek Kwiatek for their excellent field work.

Conflicts of Interest: The authors declare no conflict of interest.

\section{References}

1. Federal University of Ouro Preto (UFOP). UFOP Report on Global Market Supply 2018/2019. Available online: www.ufop.de (accessed on 4 December 2020).

2. Huang, X.Q.; Huang, T.; Hou, G.Z.; Li, L.; Hou, Y.; Lu, Y.H. Identification of QTLs for seed quality traits in rapeseed (Brassica napus L.) using recombinant inbred lines (RILs). Euphytica 2016, 210, 1. [CrossRef]

3. Liersch, A.; Bocianowski, J.; Woś, H.; Szała, L.; Sosnowska, K.; Cegielska-Taras, T. Assessment of genetic relationships in breeding lines and cultivars of Brassica napus and their implications for breeding winter oilseed rape. Crop Sci. 2016, 56, 1540-1549. [CrossRef]

4. Szała, L.; Sosnowska, K.; Popławska, W.; Liersch, A.; Olejnik, A.; Kozłowska, K. Development of new restorer lines for CMS ogura system with the use of resynthesized oilseed rape (Brassica napus L.). Breed. Sci. 2016, 66, 516-521. [CrossRef] [PubMed]

5. Niemann, J.; Bocianowski, J.; Wojciechowski, A. Effects of genotype and environment on seed quality traits variability in interspecific cross-derived Brassica lines. Euphytica 2018, 214, 193. [CrossRef]

6. Snowdon, R.J.; Iniguez Luy, F.L. Potential to improve oilseed rape and canola breeding in the genomic area. Plant Breed. 2012, 131, 351-360. [CrossRef]

7. Friedt, W.; Snowdon, R.J. Oilseed rape. In Handbook of Plant Breeding. Oil Crops; Vollmann, J., Rajcan, I., Eds.; Springer Science \& Business Media: New York, NY, USA, 2009; Volume 4, pp. 91-126.

8. Wittkop, B.; Snowdon, R.J.; Friedt, W. Status and perspectives of breeding for enhanced yield and quality of oilseed crops for Europe. Euphytica 2009, 170, 131-140. [CrossRef]

9. Möllers, C. Potential and future prospects for rapeseed oil. In Rapeseed and Canola Oil. Production, Processing, Properties and Uses; Gunstone, F.D., Ed.; Blackwell Publishing: Oxford, UK, 2009; pp. 186-212.

10. Szydłowska-Czerniak, A.; Bartkowiak-Broda, I.; Karlović, I.; Karlovits, G.; Szłyk, E. Antioxidant capacity, total phenolics, glucosinolates and colour parameters of rapeseed cultivars. Food Chem. 2011, 127, 556-563. [CrossRef] 
11. Matthäus, B.; Haase, N.; Unbehend, G. Impact of HOLL rapeseed oil during frying on product quality during storage. In Proceedings of the 13th International Rapeseed Congress, Prague, Czech Republic, 5-9 June 2011; pp. 528-531.

12. Spasibionek, S. Genetic and breeding study of winter oilseed rape mutants (Brassica napus L.) with changed fatty acid composition. In Monographs and Scientific Dissertations, Plant Breeding and Acclimatization; National Research Institute (NRI): Radzików, Poland, 2013; Volume 47, pp. 7-106. (In Polish)

13. Matthäus, B. Effect of dehulling on the composition of antinutritive compounds in various cultivars of rapeseed. Fett Lipid 1998, 100, 295-301. [CrossRef]

14. Spasibionek, S.; Mikolajczyk, K.; Cwiek-Kupczynska, H.; Pietka, T.; Krotka, K.; Matuszczak, M. Marker assisted selection of new high oleic and low linolenic winter oilseed rape (Brassica napus L.) inbred lines revealing good agricultural value. PLOS ONE 2020, 15, e0233959. [CrossRef]

15. Bocianowski, J.; Liersch, A.; Nowosad, K. Genotype by environment interaction for alkenyl glucosinolates content in winter oilseed rape (Brassica napus L.) using additive main effects and multiplicative interaction model. Curr. Plant Biol. 2020. [CrossRef]

16. Shaffi, B.; Mahler, K.A.; Price, W.J.; Auld, D.L. Genotype x environment interaction effects on winter rapeseed yield and oil content. Crop Sci. 1992, 32, 922-927. [CrossRef]

17. Moghaddam, M.J.; Pourdad, S.S. Genotype x environment interactions and simultaneous selection for high oil yield and stability in rainfed warm areas rapeseed (Brassica napus L.) from Iran. Euphytica 2011, 180, 321-335. [CrossRef]

18. Zobel, R.W.; Wright, M.J.; Gauch, H.G. Statistical analysis of yield trial. Agron. J. 1988, 80, 388-393. [CrossRef]

19. Gauch, H.G.; Zobel, R.W. Imputing missing yield trial data. Theor. Appl Genet. 1990, 79, 753-761. [CrossRef] [PubMed]

20. Spasibionek, S. New mutants of winter rapeseed (Brassica napus L.) with changed fatty acid composition. Plant Breed. 2006, 125, 259-267. [CrossRef]

21. Spasibionek, S.; Matuszczak, M.; Piętka, T.; Krótka, K.; Krzymański, J. Możliwości dalszego obniżania zawartości glukozynolanów w nasionach rzepaku podwójnie ulepszonego (Brassica napus L.). The possibilities for further reduction of the glucosinolate content in seeds of double low rapeseed (Brassica napus L.). Rośliny Oleiste Oilseed Crop. 2016, XXXVII, 21-36. (In Polish)

22. Cichy, H.; Budzianowski, G.; Cegielska-Taras, T.; Szała, L. Odmiana rzepaku ozimego wyhodowana przy użyciu podwojonych haploidów. Winter oilseed rape cultivar produced by the use of doubled haploids. Rośliny Oleiste Oilseed Crop. 2005, XXVI, 589-593. (In Polish)

23. Szała, L.; Sosnowska, K.; Cegielska-Taras, T. Induced chromosome doubling in microspores and regenarated haploid plants of Brassica Napus. Acta Biol. Crac. Bot. 2020, 62, 23-31. [CrossRef]

24. Piotrowska, A.; Krzymański, J.; Bartkowiak-Broda, I.; Krótka, K. Characteristic of yellow-seeded lines of winter oilseed rape. In Proceedings of the 11th International Rapeseed Congress, Copenhagen, Denmark, 6-10 June 2003; pp. 247-249.

25. Szała, L.; Kaczmarek, Z.; Cegielska-Taras, T.; Adamska, E. Influence of yellow-seeded parent on DH populations of Brassica napus L. obtained from reciprocal crosses between black and yellow seeded DH line. In Proceedings of the 13th International Rapeseed Congress, Praque, Czech Republic, 4-7 June 2011; pp. 741-744.

26. Bartkowiak-Broda, I.; Popławska, W.; Fürguth, A.; Mikołajczyk, K. Double low restorer lines of winter rapeseed for CMS ogura system. Rośliny Oleiste Oilseed Crop. 2003, XXIV, 343-352.

27. Poplawska, W.; Bartkowiak-Broda, I.; Szala, L. Genetic and breeding evaluation of doubled haploid lines with restorer gene for CMS Ogura system of winter oilseed rape (Brassica napus L.). Brassica 2007, 9, $29-32$.

28. Bartkowiak-Broda, I. Hodowla odmian mieszańcowych rzepaku-Breeding of oilseed rape hybrid varieties. Rośliny Oleiste Oilseed Crop. 1994, XV, 11-20. (In Polish)

29. Michalski, K.; Kołodziej, K.; Krzymański, J. Quantitative analysis of glucosinolates in seeds of oilseed rape -effect of sample preparation on analytical results. In Proceedings of the 9th International Rapeseed Congress, Cambridge, UK, 4-7 July 1995; pp. 911-913.

30. Velasco, L.; Möllers, C.; Becker, H.C. Estimation of seed weight, oil content and fatty acid composition in intact single seeds of rapeseed (Brassica napus L.) by near infrared reflectance spectroscopy. Euphytica 1999, 106, 79-85. [CrossRef] 
31. Mikolajczyk, K.; Dabert, M.; Karlowski, W.M.; Spasibionek, S.; Nowakowska, J.; Cegielska-Taras, T. Allele-specific SNP markers for the new low linolenic mutant genotype of winter oilseed rape. Plant Breed. 2010, 129, 502-507. [CrossRef]

32. Falentin, C.; Brégeon, M.; Lucas, M.O.; Renard, M. Genetic Markers for High Oleic Content in Plants. International Patent Publication No. WO 2007/138444, 6 December 2007.

33. Matuszczak, M.; Spasibionek, S.; Gacek, K.; Bartkowiak-Broda, I. Cleaved amplified polymorphic seguences (CAPS) marker for identification of two mutant alleles of the rapeseed BnaA.FAD2 gene. Mol. Biol. Rep. 2020. [CrossRef]

34. Mikolajczyk, K.; Bartkowiak-Broda, I.; Poplawska, W.; Spasibionek, S.; Dobrzycka, A.; Dabert, M. A multiplex fluorescent PCR assay in molecular breeding of oilseed rape. In Plant Breeding; Ibrokhim, Y., Ed.; InTech: Rijeka, Croatia, 2011; pp. 185-200.

35. Nowosad, K.; Liersch, A.; Popławska, W.; Bocianowski, J. Genotype by environment interaction for seed yield in rapeseed (Brassica napus L.) using additive main effects and multiplicative interaction model. Euphytica 2016, 208, 187-194. [CrossRef]

36. Purchase, J.L.; Hatting, H.; van Deventer, C.S. Genotype $\times$ environment interaction of winter wheat (Triticum aestivum L.) in South Africa: II. Stability analysis of yield performance. S. Afr. J. Plant Soil 2000, 17, 101-107. [CrossRef]

37. Nowosad, K.; Liersch, A.; Poplawska, W.; Bocianowski, J. Genotype by environment interaction for oil content in winter oilseed rape (Brassica napus L.) using additive main effects and multiplicative interaction model. Indian J. Genet. Plant Breed. 2017, 77, 293-297. [CrossRef]

38. Farshadfar, E.; Sutka, J. Locating QTLs controlling adaptation in wheat using AMMI model. Cereal Res. Commun. 2003, 31, 249-256. [CrossRef]

39. Bocianowski, J.; Niemann, J.; Nowosad, K. Genotype-by-environment interaction for seed quality traits in interspecific cross-derived Brassica lines using additive main effects and multiplicative interaction model. Euphytica 2019, 215, 7. [CrossRef]

40. Friedt., W.; Lühs, W.W. Breeding of rapeseed (Brassica napus) for modified seed quality-Synergy of conventional and modern approaches. In Proceedings of the 10th International Rapeseed Congress, Canberra, Australia, 26-29 September 1999.

41. Engqvist, M.G.; Becker, H.C. Correlation studies for agronomic traits in segregating families of spring oilseed rape (Brassica napus). Hereditas 1993, 118, 211-216. [CrossRef]

42. Würschum, T.; Liu, W.; Maurer, H.P.; Abel, S.; Reif, J.C. Dissecting the genetic architecture of agronomic traits in multiple segregating populations in rapeseed (Brassica napus L.). Theor Appl Genet. 2012, 124, 153-161. [CrossRef]

43. Zou, J.; Zhao, Y.; Liu, P.; Shi, L.; Wang, X.; Wang, M. Seed quality traits can be predicted with high accuracy in Brassica napus using genomic data. PLoS ONE 2016, 11, e0166624. [CrossRef]

44. Zhao, J.; Becker, H.C.; Zhang, D.; Zhang, Y.; Ecke, W. Oil content in an European $x$ Chinese rapeseed population: QTL with additive and epistatic effects and their genotype-environment interaction. Crop Sci. 2005, 45, 51-59.

45. Delourme, R.; Falentin, C.; Huteau, V.; Clouet, V.; Horvais, R.; Gandon, B. Genetic control of oil content in oilseed rape (Brassica napus L.). Theor Appl Genet. 2006, 113, 1331-1345. [CrossRef] [PubMed]

46. Liersch, A.; Bocianowski, J.; Bartkowiak-Broda, I. Fatty acid and glucosinolates level in seeds of different types of winter oilseed cultivars (Brassica napus L.). Commun. Biometry Crop Sci. 2013, 8, 39-47.

47. Connor, D.J.; Hall, A.J. Sunflower physiology. In Sunflower Technology and Production; Schneiter, A.A., Ed.; Amarican Society of Agronomy: Madison, WI, USA, 1997; Volume 35, pp. 113-182.

48. Pritchard, F.M.; Eagles, H.A.; Norton, R.M.; Salisbury, P.A.; Nicolas, M. Environmental effects on seed composition of Victorian canola. Seed 2000, 40, 679-685. [CrossRef]

49. Guo, J.; Wang, N.; Wen, J.; Yi, B.; Ma, C.; Tu, J.; Zou, J.; Fu, T.; Schen, J. Genetic effects and genotype $x$ environment interactions govern seed oil content in Brassica napus L. BMC Genet. 2017, 18, 1. [CrossRef] [PubMed]

50. Si, P.; Mailer, R.J.; Galwye, N.; Turner, D.W. Influence of genotype and environment on oil and protein concentrations of canola (Brassica napus L.) grown across southern Australia. Aust. J. Agric. Res. 2003, 54, 397-407. [CrossRef] 
51. Sang, J.P.; Minchinton, I.R.; Johnstone, P.K.; Truscott, R.J.W. Glucosinolates profiles in the seed, root and leaf tissue of cabbage, mustard, rapeseed, radish and swede. Can. J. Plant Sci. 1984, 64, 77-93. [CrossRef]

52. Magrath, R.; Herron, C.; Giamoustaris, A.; Mithen, R. The inheritance of aliphatic glucosinolates in Brassica napus. Plant Breed. 1993, 111, 55-72. [CrossRef]

53. Padilla, G.; Cartea, M.E.; Velasco, P.; De Haro, A.; Ordás, A. Variation of glucosinoaltes in vegetable crops of Brassica rapa. Phytochemistry 2007, 68, 536-545. [CrossRef] [PubMed]

54. Zhao, F.J.; Evans, E.J.; Bilsborrow, P.E.; Syers, J.K. Influence of nitrogen and sulphur on the glucosinolate profile of rapeseed (Brassica napus L.). J. Sci. Food Agric. 1994, 64, 295-304. [CrossRef]

55. Rosa, E.A.S.; Heaney, R.K.; Fenwick, G.R.; Portas, C.A.M. Glucosinolates in crop plants. Hortic. Rev. 1997, 19, 99-215.

56. Cartea, M.E.; Rodríguez, V.M.; De Haro, A.; Velasco, P.; Ordás, A. Variation of glucosinoaltes and nutritional value in nabicol (Brassica napus pabularia group). Euphytica 2008, 159, 111-122. [CrossRef]

57. Chen, B.; Xu, K.; Li, H.; Gao, G. Evaluation of quality traits and their genetic variation in global collection of Brassica napus L. Plant Genet. Resour. 2018, 16, 146-155. [CrossRef]

58. Golkari, S.; Haghparast, R.; Roohi, E.; Mobasser, S.; Ahmadi, M.M.; Soleimani, K. Multi-environment evaluation of winter bread wheat genotypes under rainfed conditions of Iran-using AMMI model. Crop Breed. J. 2016, 6, 17-31. [CrossRef]

59. Yan, W.; Hunt, L.A. Genotype by environment interaction and crop yield. Plant Breed. Rev. 1998, 16, $135-178$. [CrossRef]

60. Vargas, W.; Crossa, J.; van Eeuwijk, F.A.; Ramirez, E.; Sayre, K. Using partial least squares regression, factorial regression and AMMI models for interpreting genotype-by-environment interaction. Crop Sci. 1999, 39, 955-967. [CrossRef]

61. Hristov, N.; Mladenov, N.; Djuric, V.; Kondic-Spika, A.; Marjanovic-Jeromela, A.; Simic, D. Genotype by environment interactions in wheat quality breeding programs in southeast Europe. Euphytica 2010, 174, 315-324. [CrossRef]

Publisher's Note: MDPI stays neutral with regard to jurisdictional claims in published maps and institutional affiliations.

(C) 2020 by the authors. Licensee MDPI, Basel, Switzerland. This article is an open access article distributed under the terms and conditions of the Creative Commons Attribution (CC BY) license (http://creativecommons.org/licenses/by/4.0/). 